\title{
The four strongest earthquakes in Tyrol/ Austria during XVIth and XVIIth centuries: from archival sources to macroseismic intensities
}

\author{
Christa Hammerl
}

Received: 26 September 2014 / Accepted: 3 November 2014 / Published online: 16 January 2015 (C) Akadémiai Kiadó 2014

\begin{abstract}
Knowledge of historical earthquakes has become more important in recent years. Complete and accurate information is necessary in order to carry out a coherent seismic hazard assessment of a specific area. In particular, since the introduction of Eurocode- 8 , the building code for the construction of earthquake-resistant buildings in Europe, the importance of new assessments of historical earthquakes due to the state of the art has increased, as the assessment period for the determination of seismic hazard was extended from 100 to more than 450 years.

Tyrol has repeatedly been exposed to stronger earthquakes in the past. The four strongest, previously known earthquakes were reviewed and re-assessed for the first time according to the state of the art. These were: 1. November 1571, 4. January 1572, 17. July 1670 and 22. December 1689.

Within the INTERREG IV A project HAREIA-Historical and Recent Earthquakes in Italy and Austria (2009-2012), existing interpretations for the mentioned damaging earthquakes in Tyrol were analysed and the historical information was checked and completed by means of contemporary sources from the archives.

The earthquake of 1571 could be identified as a fake and the epicentral intensity of the 1572 earthquake was downgraded due to the information of the contemporary sources. Several new sources have been found in the archives for the earthquakes of 1670 and 1689, which leads to much more detailed knowledge of the events.

An important result of this study is, among other things, that for the first time macroseismic data points are available, which allows transparency in the assessment of the new parameters and contributes to the seismic history of single locations.
\end{abstract}

Keywords Historical earthquakes $\cdot$ Seismic hazard · Original sources

C. Hammerl $(\bowtie)$

ZAMG, Vienna, Austria

e-mail: christa.hammerl@zamg.ac.at 


\section{Introduction: historical earthquake research in Tyrol/Austria}

Knowledge of historical earthquakes has become more important in recent years. Complete and accurate information is necessary in order to carry out a coherent seismic hazard assessment of a specific area. In particular, since the introduction of Eurocode-8, the building code for the construction of earthquake-resistant buildings in Europe, the importance of new assessments of historical earthquakes due to the state of the art has increased, as the assessment period for the determination of seismic hazard was extended from 100 to more than 450 years.

For seismic hazard assessment, earthquakes that occurred prior to the instrumental period must be considered. Due to the relatively long "return periods" of stronger earthquakes in Austria, the interpretation of historical earthquakes is of great importance.

Tyrol has repeatedly been exposed to stronger earthquakes in the past (Fig. 1). The four strongest, previously known earthquakes were reviewed and re-assessed for the first time according to the state of the art. These were:

1st November 1571

4th January 1572

17 th July 1670

22nd December 1689

Within the INTERREG IV A project HAREIA ${ }^{1}$, existing interpretations for the below mentioned damaging earthquakes in Tyrol were analysed and the historical information was checked and completed by means of contemporary sources from the archives. The earthquake of 1571 could be identified as a fake and the epicentral intensity of the 1572 earthquake was downgraded due to the information of the contemporary sources. Several new sources have been found in the archives for the earthquakes of 1670 and 1689, which leads to much more detailed knowledge of the events.

An important result of this study is, among other things, that for the first time macroseismic data points are available, which allows transparency in the assessment of the new parameters and contributes to the seismic history of single locations.

\section{The earthquake of November 1st, 1571}

In the Austrian earthquake catalogue (AEC) the "quake" of November 1st, 1571, was listed with an epicentral intensity of $7^{\circ}$ EMS 98. Intensive studies in the framework of the INTERREG IV A project HAREIA resulted in the following conclusions, which are summarized here briefly:

On November 1st, 1571, no damaging earthquake occurred in Tyrol. The date November 1st correlates with the "Great Flood" in the Netherlands in 1570, which was mentioned in connection with an earthquake by, for example, the geologists Von Hoff (1840) and Keferstein (1826). Von Hoff wrote: "1571 on November 1st, when the great devastating flood "Springfluth" happened to the Dutch coasts, an earthquake could have been in Innsbruck."

It's a question of misinterpretation of the historical sources and is confirmed due to the lack of relevant information in the Innsbruck and Haller Council minutes. This type of occurrence is common in historical earthquake research.

1 INTERREG IV A project HAREIA-Historical and Recent Earthquakes in Italy and Austria (2009_ 2012) https://www.zamg.ac.at/cms/de/forschung/geophysik/historische-erdbebenforschung/hareia-historical -and-recent-earthquakes-in-italy-and-austria. Accessed 17.9.2014. 


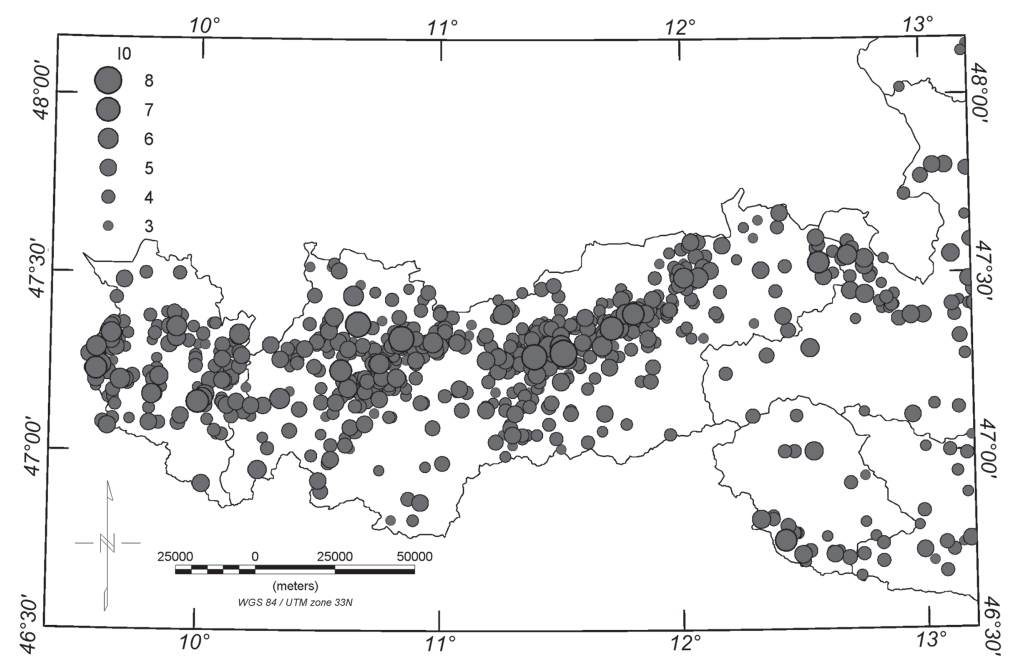

Fig. 1 The historical seismicity in Tyrol is characterized by a moderate activity and is one of the most seismic active areas of Austria. The figure shows earthquakes with $\mathrm{I}_{0} \geq 3^{\circ}$ EMS-98 from 2000-2012. Source ZAMG AEC

Future files of the Austrian earthquake catalogue will list this "earthquake" of 1571 as a "fake" because of the misinterpretation of the sources.

\section{The earthquake on January 4th, 1572}

The earthquake on January 4th, 1572, is one of the stronger known historical earthquakes in Tyrol. Until this study, this quake was listed in the AEC with an epicentral intensity $\mathrm{I}_{0}=8^{\circ}$ EMS-98 and the epicenter in Innsbruck.

\subsection{Historical source examples: a selection}

The eyewitness Jacob of Boimont zu Pairsberg, ambassador of the Bishop of Bressanone and Trento and governor of Innsbruck's government, wrote in his autobiography (Straganz 1896) that on January 4th, 1572, between 7-8 p.m. a great earthquake occurred in Innsbruck. It continued throughout the night with larger and smaller aftershocks. Many houses showed cracks, chimneys collapsed from the roofs and ovens were damaged.

The city council of Innsbruck reports: "Rath gehalten am 5 tag January 1572. Erdbidem

Angestert Freytags zu nacht vmb acht Vr ist der groß Erdpidem gewesen, vnd darauf ist dieselbig nacht biß an den morgen Nachent alle halbe stund ain Erdbidem gewesen, vnd sounderlichen ist anheut morgens vmb 7 vhr auch ain grosser Erdbidem khumen. Darnach haben sie weilenwey $\beta$ Nachgelassen. Der allmechtige Got wolle vnns gnedig vnd barmherzig sein vnnd seinen Zorn von Uns abwenden." (StAI, Ratsprotokoll 1572, fol. 141r.) (Fig. 2).

As late as July 14th, 1572, one still finds an entry in these reports regarding the so-called Innturm (the town tower was razed in the 18th century), which was so heavily damaged by the main shock and the many aftershocks that the top had to be demolished and later rebuilt.

Another contemporary witness, Melchior Hannibal, Freiherr von Wolkenstein, wrote a multi-page, detailed "Bericht über den Schaden etc. den das Erdbeben am grossen 


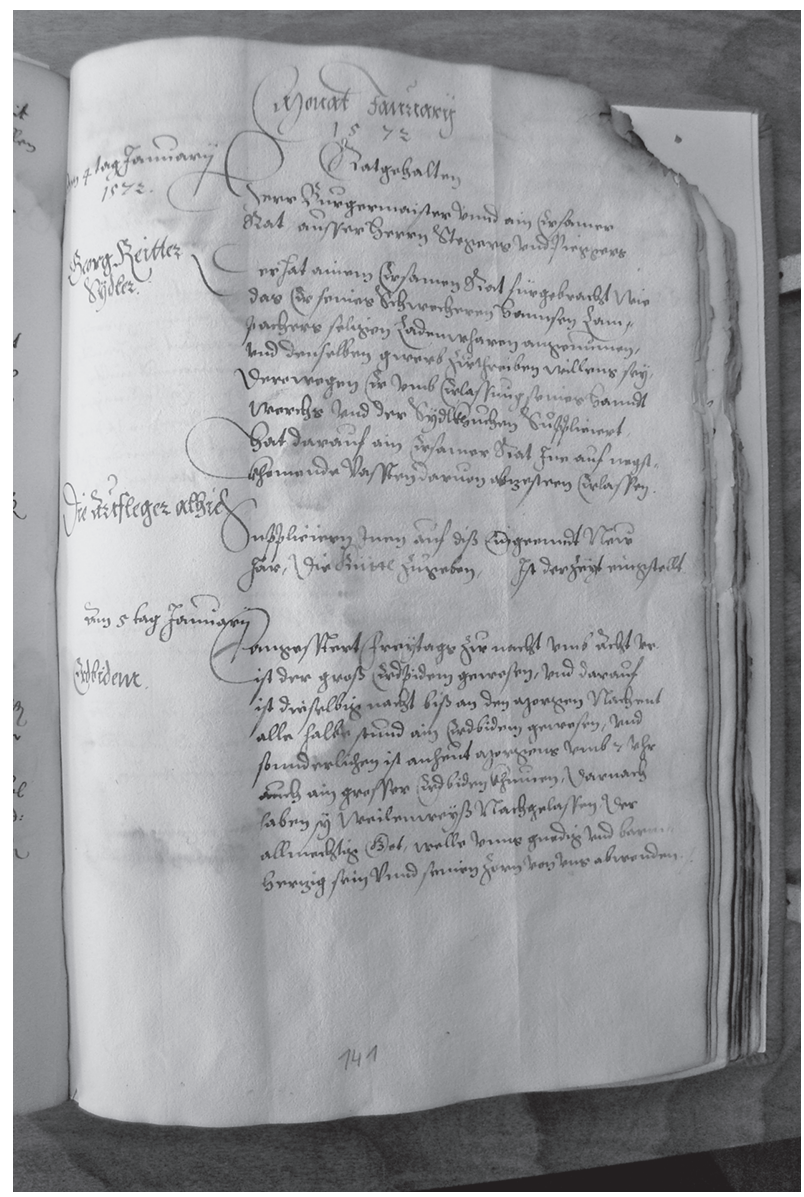

Fig. 2 Earthquake of January 4th, 1572 : Municipal archive Innsbruck, Minutes of the Council of Innsbruck 1572, fol. 141r. Photo: Ch. Hammerl

bisch.[öflichen] Hause in Innsbruck angerichtet hat - report on the damage by the earthquake to the Episcopal Palace in Innsbruck", dated on February 10th, 1572, to the prince-bishop of Bressanone Johann VI. Thomas Spaur; in this report he described the Stamser- or Brixner house at Domplatz \# 2. Among other things he noted the damage and the repair work "... das gemeyr so die erbiden Etlich Zinen vnd sonsten Oben herumb Erschitt vnd abgeworffen... die Klifft auß Zubessern ... bey dem Turn hinden vnd forn 6 Eissne schleider einzulegen”, but above all he mentioned repeatedly the generally poor structural condition of the house (Erzdiözese Brixen 1572).

The Tyrolean Chamber (Neuhof, Golden Roof, Herzog-Friedrich-Straße Nr. 15) was heavily damaged by the earthquake, "zerschitt und zerschifert", as well. The walls had to be hold together with iron cramps (Felmayer et al. 1986).

The contemporary witness Franz Schweyger, organist and sacristan at St. Nikolaus, reported in the Chronik der Stadt Hall (Schönherr 1867) a foreshock, the main shock and the many aftershocks in Hall in Tirol. 
Table 1 Macroseismic data points (MDPs) of the January 4th, 1572 earthquake

\begin{tabular}{llll}
\hline Locality & Long. & Lat. & Intensity EMS-98 \\
\hline Absam & 11.500 & 47.300 & $\mathrm{D} \triangleq \max .6$ \\
Hall in Tirol & 11.517 & 47.283 & $\mathrm{D} \triangleq \max .6$ \\
Innsbruck & 11.400 & 47.267 & $\mathrm{D} \triangleq 6-7$ \\
Kundl & 11.986 & 47.470 & $\mathrm{~F} \triangleq 3-4$ \\
Schwaz & 11.700 & 47.333 & $\mathrm{~F}$ max.5 \\
Wattenberg & 11.606 & 47.272 & $\mathrm{~F} \triangleq 3-5$ \\
\hline
\end{tabular}

Egger (1949) mentioned in his chronicle of Hall repair work on the tower of the Parish church, “... dass der Pfarrkirchturm, zugleich städtischer Aussichts- und Wartturm, auf städtische Kosten geschleudert wurde. Zu diesem Zwecke wurde ein hängendes Gerüst an den Fenstern befestigt, von innern heraus die Mauer durchbohrt und auf allen vier Seiten die Schleudern eingezogen. Es wurden dazu 53 alte Zentner Eisen. ${ }^{2}$ gebraucht."

Even the causes of earthquakes were a topic, for example, in a letter to the sovereignMandat Vonwegen abstellung des Sündtlichen vnd vnpuesfertigen Lebens-, the natural event was explained as God's punishment because of the people's amoral lifestyles: "dass der allmächtige Gott hier und an anderen Orten uns mit dem schrecklichen und grausamen noch nie zuvor gehörten Erdbeben heimgesucht hat, weil keine Buße und Besserung des Lebens gespürt wird..."

That the people lived in fear and that the quake was described as God's punishment is also seen clearly in the earthquake aftermath. After the terrible earthquake, processions such as those on Corpus Christi were carried out in Hall on the 11th, 14th and 16th January 1572. Hall was a center of Protestantism in Tyrol, resulting particularly in the first half of the 16th century in religious riots in the Wake of the Reformation. Social disciplining was an effective means of Counter-Reformation. A letter dated January 8th, 1572, could be an example for this; the government threatened residents with punishment if they would oppose said regulations: "Haltung der Gottesdienst vnnd Procesionen von wegen der Erschrockhlichen Erdpidem

... Desgleichen am mittwoch solls das ambt von vnsere lieben Frauen vnnd am Freytag von dem Leiden Cristi, gesungen vnnd darauf der vmbgang gehalten, auch dieselben drey tag gefastet, vnnd alle Laden vnnd Cramer vormittag zugesperrt, auch die Arbait eingestellt worden ... vnnd daneben das volkh zu der Pueß vnnd besserung vermanen lasset, auch verordnung thuet, das alle Eurere Zugethanen, solches Gotßdienst, vnnd Processiones fleißig vnnd mit grosser andacht besuchen, vnnd gegen den Vngehorsamen mit straffen verfaret ..." (TLA, Regierungskopialbücher 1572).

Within the project, contemporary sources were searched for in the archives and were source-critically interpreted in the following. Due to these historical sources, the original epicenter in Innsbruck could be confirmed and the epicentral intensity was downgraded to 6-7 $7^{\circ}$ EMS-98, which, according to the EMS-98 scale, means that many people were frightened by the quake and ran outdoors. Slight to moderate structural damage such as small cracks in walls, fall of plaster, falling of chimney parts was observed, and for buildings in a bad state of construction, as was partly the case in Innsbruck and Hall, large cracks could have occurred and partitions collapsed.

The quake on Friday January 4th, 1572, occurred at 18.45 UTC. Damage was reported in Innsbruck, Hall and Absam and it was felt in Kundl, Schwaz and Wattenberg (Table 1).

2 In the sixteenth century in Tyrol: 1 Zentner $=56.6 \mathrm{~kg}$, after Sandgruber (1995), p. 585 . 


\section{The earthquake of July 17th, 1670 in Hall in Tirol}

Hall in the County of Tyrol was first mentioned as a salina (saltern). The current name dates back to 1256, similar to Halle, Hallein, Schwäbisch Hall or Hallstatt, which refers to the Celtic word for salt. From the thirteenth century onwards, the salt mine formed the main industry of the town and its surroundings.

In the fifteenth and sixteenth century, Hall was one of the most important towns in the Habsburg Empire. This period also saw the construction of many of the churches, monasteries and convents that up until present day shaped the appearance of the town. Today Hall has the biggest intact old town in the western part of Austria.

One of the strongest earthquakes that ever afflicted the Tyrolean area was probably that of July 17th, 1670. Many houses in Hall were damaged during the earthquake and some collapsed. Trunks were quickly erected to support many of the affected houses. Later, socalled earthquake walls, buttresses made of Höttinger breccia that still dominate the cityscape, reinforced many houses in Hall and Innsbruck (Fig. 3).

Fig. 3 So-called earthquake walls, buttresses made of Höttinger breccia, reinforce many houses in Hall and Innsbruck. They still dominate the cityscape. Photo: Ch. Hammerl

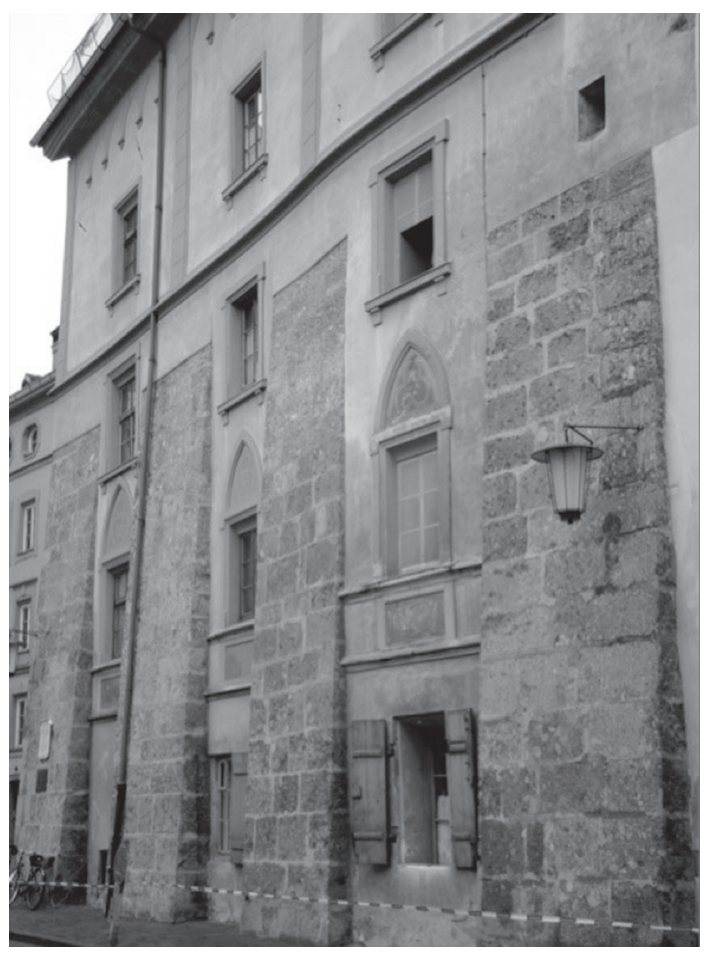

Many contemporary texts reported on the earthquake of July 17th, 1670, like the Tyrolean nobleman Johannes Sigmund von Rost zu Kehlburg und Aufhofen (1653-1729), later curator of St. Michael Castle (St. Lorenzen in South Tyrol). He was studying in Innsbruck when the quake occurred and noted in his diary (Humberdrotz 1956), in amazingly clear and precise words, what happened during and after the earthquake in Innsbruck and Hall. He mentioned those earthquake effects that are important for intensity estimation according to the EMS-98 scale: 
"Ybrigens hab ich zu Insprugg weil ich gstudiert ausser etlich schenen Comedien wenig denkwirdiges gschöchen; doch aber mueß ich gleichwol auch eine Meldung tun von jenigen großen Ertpiden, so anno 1670 in Monat Juli an St. Alexii Nacht zwischen 2 und 3 Uhr zu Hall und Insprugg ... maistens seint verspirt worden..."

The earthquakes continued from 2 a.m. until the next day, but were not as strong as in the beginning. The end of these earthquake series was only half a year later. What fright and what a grim time it was during this period in Innsbruck and Hall, one can only imagine from the following description: “... indeme der erste in der Nacht so starckh und greilich gewesen, daß sich etlich Gloggen von selbsten geliten, deren Thon ich und vil ander Persohnen in wenigisten nicht gehert."

"Als nun volgents der Tag angeprochen und dise Forcht in etwas gewichen, hat man ainen ohne Huet, den andern ohne Schuech oder Strimpf, den 3ten nur in Hosen etlich wol auch allein in Hemat gesöchen, dass aso nicht der 10ente recht beclaidet ware. Mann hat wol kheinen lachendt, sondern alswann halbs Tote daher giengen, gesöchen. Zu Insprugg doch ist (Got Lob) ein ieder mit Leben darvon khumben, seint auch die Heiser bei weiten nicht so verderbt worden als wie zu Hall."

Three days after the earthquake, Von Rost visited Hall. He saw many houses completely devastated and the tower of the parish church partly collapsed, whereby people were killed. Many people had to live in tents for some time (Fig. 4).

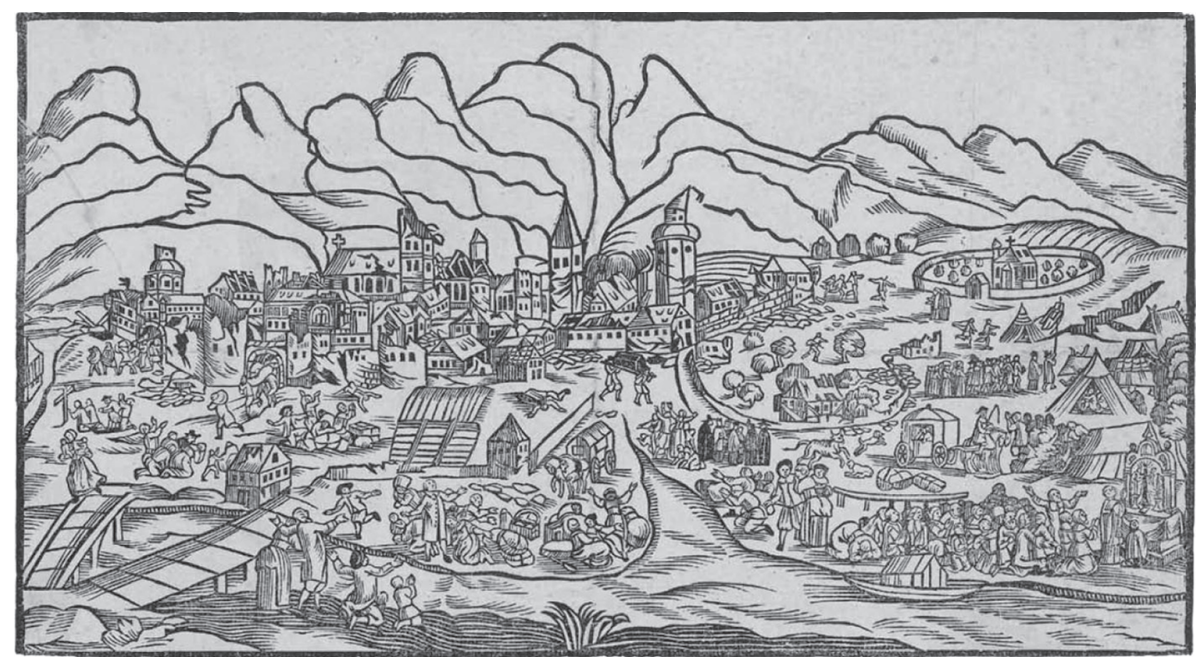

Fig. 4 Pamphlet by Elias Wellhöfer (1650-1681), Augsburg, reporting of the earthquake in 1670 (woodcut). Museum in Hall in Tirol, Inv. Nr. $431,40 \times 32 \mathrm{~cm}^{2}$. Photo: Watzek Photografie

Due to the earthquake, an additional building northeast of the old castle in Innsbruck was built. Court architect Christoph Gumpp planned an earthquake-resistant residence made of wood for Anna de' Medici, widow of Archduke Ferdinand Karl, and her daughter Claudia Felicitas. The construction was carried out in 1670 after the earthquake. The new extraordinary residence was actually earthquake-resistant, but burned down at last in 1728 (Weigl 2007). 


\subsection{The effects of the earthquake in Hall in Tirol}

On the very day after the catastrophic event, the mayor of Hall in Tirol reported: "... wie ... durch den 17 dis frue vngefehr vmb 2 Vhr durch Gott verhenckhten Erpidem, in der Statt sowol in Khirch thurm, heissern stattmauern vnd anderen orth Erschrekh[licher]schaden beschehen, auch die heiser Eingefallen vnd Etlich personen erschlagen worden ..." Again, it was noted that God's "just anger" should be averted by prayers and one sermon and then the town's master builder and master carpenter should evaluate the damage (StAH, Ratsprotokolle, 1670, fol 36v.).

Months after the main quake of July 17th, there were still requests for help addressed to the city council of Hall concerning either repair work or financial support: “... den 3 Septembris anno 1670 Maister Gisser ... mit nachparn in der schmidt gassen, biten Ihnen maurern zu schaffen, damit nur die Camin vnd anderer notwendigkheit gemacht werden solle." These concerns were rejected, as the town itself suffered from shortage, "selbsten mangl leidet", and therefore the citizens themselves should take care of repair works (StAH, Ratsprotokolle 1670 , fol 48r.).

“Datum 17 Septembris 1670 ... Brigitha Zanin bitet vmb Etlich wochen lohn Ihres durch den Thurm [Note: Tower of St. Nikolaus] erschlagenen vaters.” Brigitha Zanin asked for her deceased father's salary, as the collapsing tower had killed her father. In this special case the city council hesitated with the order and pushed it on the back burner (StAH, Ratsprotokolle 1670 , fol 50v.). On the contrary, the schoolmaster's request, from 26th September for “... reparierung der schuelen vnd öfen” was immediately approved (StAH, Ratsprotokolle 1670, fol 54r.). On November 28th, 1670, six carpenter's servants asked for compensation because of their dangerous and exhausting reconstruction work “... so in disem Erpidens ruinierung in 4 monathen lang mit leib vnd leben gearbeithet ..." This request was denied (StAH, Ratsprotokolle 1670, fol 66r.).

The earthquake was also a catalyst for unusual requests: Adelheid Saurwein, wife of Jacob Saurwein, who was the owner of the house in the Salvatorgasse 4 and cutter of the salt bags by trade Pfannhaussalzsackschneider, in the letter (TLA, Salinenarchiv, 1670, p. 183) of September 17th, 1670, requested of the Councils and the president of the O. Ö. Hofkammer the assignment of the Salzsackschneiderdienstes in the case of her husband's "early passing" "... im fahl seines zeitlichen hintrits", after he suffered a stroke due to the earthquake “... Ihr Ehewürth Jacob Saurwein nach Jüngst entstandenen Erdpidumb mit dem schlag also berüert worden, das seiner reconualescenz halber ohne sonderbahre hilff Gottes khein hoffnung zumachen ..."

A good basis for reconstructing the damages caused by the earthquake of 1670 in Hall is the Dreifache Chronik der Stadt Hall im Innthale (Seeböck 1882). In this chronicle there is an accurate description of buildings damaged by the earthquake in the "Verzeichniss deren, durch obgemelten beschenen Erdpiden, eingfallnen, vnd mit grossen Flosss Päumen auf den gassen Vnterstizten häusern, so den 26 July abgezehlet worden [1670] (Seeböck 1882, p. 314). Moser (Moser 1989) used this chronicle inter alia as a basis for his comprehensive publication on the development of the old town of Hall, in which he also considered the damages caused by the earthquake.

In the following, damages in Hall are given by way of example. The information derives, unless otherwise noted, from the chronicle mentioned above:

Secular buildings: North town gate Absam: heavy damage; Agramsgasse: damage, Nr. 5 heavy damage (complete collapse 13. August) and Nr. 23 (Fig. 5), the damage here was probably a secondary damage caused by the nearby partially-collapsed tower (Frauenturm); Arbesgasse: damage, Nr. 6 heavy damage; well at Oberer Stadtplatz: ruined; 
Egelhauser gate in the West: damage; Eugenstraße: heavy damage; Krippgasse: damage; Langer Graben: damage, Nr. 2 collapse of a wall; Münzergasse: damage; Münzer gate in South: heavy damage; Münzer tower and dwelling of mint's journeymen: heavy damage; Mustergasse: Nr. 3 damage; Oberer Stadtplatz: Nr. 4, 5 damage and Nr. 6 (former Fürstenhaus), partial collapse, earthquake victims were also reported (Pfarrarchiv Hall in Tirol: Totenbuch 1667-1683, p. 56r.); Rosengasse: damage, collapse of a house, here earthquake victims were also reported (Pfarrarchiv Hall in Tirol: Totenbuch 1667-1683, p. 56r.); Salvatorgasse: heavy damage, Nr. 25 collapse most probably caused by this earthquake; Salzpfannhaus: damage; Schergentorgasse: Nr. 2: damage; Schlossergasse: damage; Schmiedgasse: heavy damage, Nr. 11 heavy damage, Nr. 12 collapse (with mortal casualties), Nr. 13 heavy damage; Unterer Stadtplatz: Nr. 2-6, parts of the city wall collapsed in the former fish trench, thereby also house no. 2 was severely damaged; Schmiedtor in the West: damage; Waldaufstraße: damage, Nr. 16 "Ansitz" (estate) Rainegg of the so called Salzmaier, a sovereign of the country, Freiherr Franz von Wicka: heavy damage; Wallpachgasse: damage, two houses collapsed.

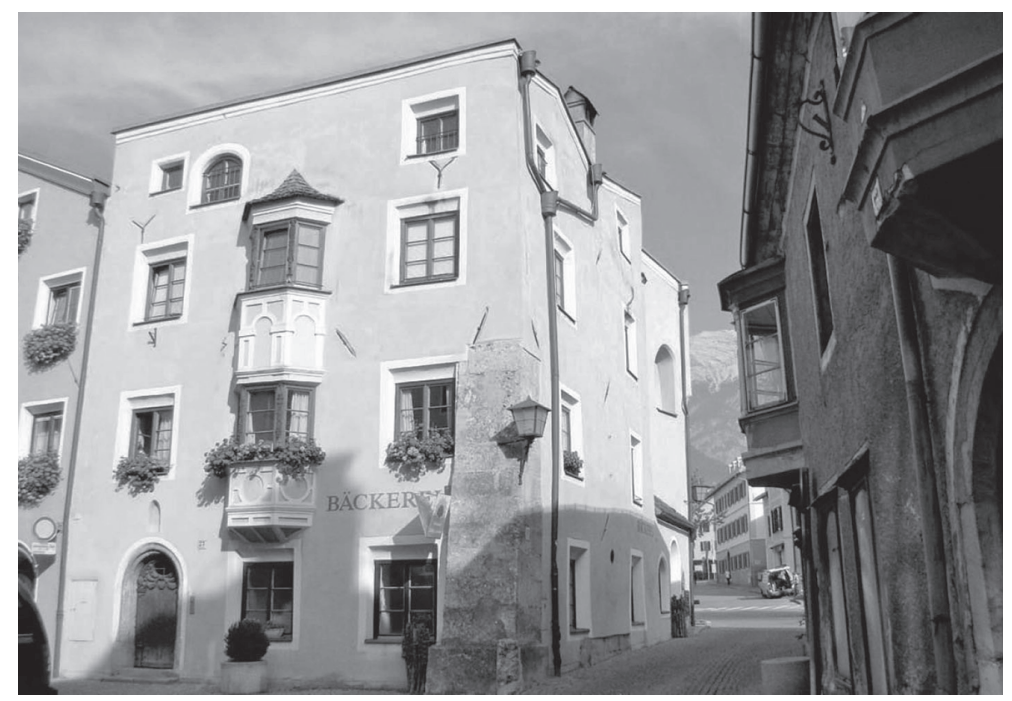

Fig. 5 Probably the heavy damage to the house Agramsgasse 23 was a secondary effect, caused by the partial collapse of the Frauenturm. Earthquake walls, buttresses made of Höttinger breccia were erected and the walls were hold together with iron cramps after the quake. Photo: Ch. Hammerl

Sacred buildings: Damenstift: damage; Jesuit Colleg and Jesuit chruch: heavy damage, especially of the monastery; Franciscan church and Franciscan monastery: damage; Saint Sebastian church or "Garttner Kirchl" (Erzdiözese Brixen: Konsistorialakten 1670) (Note: Today's site of the Hall Psychiatric Hospital, in the Thurnfeldgasse): heavy damage; parish church Saint Nikolaus: damage, tower partially collapsed, whether the Wolfgang Chapel, today's St. Joseph's Chapel was damaged on the north side of the parish church by the collapsing tower can not be confirmed from the sources: "Wolloblicher Statt Pfarrkirchen Thurn bei S. Nicolaus ist biss Zu dem Gloggenstuel eingefallen, herunder auf den Freydhoff und den Plaz, mit verschmetterung eines thails des gewölbs auf der Sacristey, jedoch ohne sonderbare weitere beschädigung." (Seeböck 1882, pp. 317-318). Additionally, one of the two tower guards was killed: "In gemelten thurn ist einer auss den Zween wachteren Zu thott geschla- 
gen worden, der ander hatt sich nach vierthalb stunden mit harter mühe aussgearbeitet, und darvon khommen." (Seeböck 1882, pp. 317-318). The tower guard could not be buried before 12 August because he was trapped under the rubble. “... gewesten Hochwachter auf dem Pfarrthurn ... welcher dem 17 July selbig erschröckhlich vorganngnen Erdpiden wegen Ein gefahlnen Pfarrthurns erpärmblich zerqwetscht vnd erst gefunden." (Pfarrarchiv Hall in Tirol: Totenbuch 1667-1683, p. 57). Saint Veit church (Note: Chapel in the cemetery west of City Hall demolished in 1840): damage; Hospital and former Hospital Church Holy Ghost Church: heavy damage, demolished after the earthquake and rebuilt in the years 1727/1728; Salvator Church: heavy damage, "Unsers lieben herren Gottshauss ist ubel geschrandet, und dessen thails eingefalner thurn, mit groser gefahr der benachbärten Zweyen häusern, sich khaum noch in der höhe haltet, und gleichsamb noch in dem lufft hanget." This upper part of the tower had to be removed after the quake by a courageous person: “... Welchen hernach ein Waaghals umb 3. Duggaten abgenommen ..."

The chronicler of the "Dreifachen Chronik" further wrote: "Hoch ist sich Zuuerwunderen, das in disem villfaltigem einfallen der häuseren, Maueren, und Caminen, durch die gnad Gottes weder Mensch noch Vieh, verlezt worden, aussgenommen ein Pferd in der Schmidgassen, und die Siben oben benante Persohnen so gar Thott gebliben.

Seind also disen 26: Jully Stizen oder Spreizen, mit denen die häuser nothwendig unterstizet von aussen auf den gassen müssen werden (ohne die in den häuseren) 200 gezehlet worden, Zu denen nach und nach mehr alss noch sovill khommen." (Seeböck 1882, p. 318).

By August 3rd, 1670, 447 wooden trunks were counted in the streets of Hall. (Seeböck 1882, 321) (Fig. 6).

The fact that such an amount of wood was immediately available for the trunks is related to the Saline, which had stored plentiful wood at the Inn riverbank in Hall for firing the saltpans for salt extraction. From the Saline Official Book of September 8, 1670, it is clear that the wood came from the Saline: “... das das Jenige holz so hin vnd wider denen Partheuen leihens weiss abgegeben worden, nit so gleich widerumben abgeforderet werden khan, in bedenkhen selbiges annoch vnter den Paufelligen gemeuer für Pelz vnd Stizen [Note "Pölzen" und Stützen] unemperlich gebraucht würdet ...” (TLA, Salinenarchiv, 1670, p. 213 r.,v.)

The pastor in Hall, Stephan Gifl, was worried about the severe damage to "his" Church of St. Nikolaus and on all other buildings in Hall. At the same time he was concerned about the church service, which was not possible in the usual form, and he feared the absence of believers. “... bis 18: Oktober kein Gottesdienst in der Pfarrkirche gehalten worden sondern bey dem PP Franciscanern ..." Therefore, the "holy sacrament" of the parish church of St. Nikolaus was transferred to the Franciscan church on July 18th and kept there until October 17th (Tinkhauser and Rapp 1879).

Nine days after the big quake, Gifl wrote a multi-page letter to the Consistory in Brixen, in which he expressed his deep concern: "Den 17. tag diss Monaths July, alsobald nach 2. Vhr friee hat ain erschöckhliche bewogendter Erdpiden, ... den Pfarr: thurn schier gar biß $z u$ den gloggen stuel vmb: vnd nider geworffen, daß Kirchen gewelb an 3.orthen zimblich eröffnet, hin vnd wider merckhlichen gekhlifftet, vnd gespaltet, die Zirathen oder Gratt deß Gwelbs thails herab geworffen, thails vnd maistens abgelediget, haben also vn $\beta$, den dato an, dises Vnsern lieben, aber armseligen Gottshauses zu haltung Vnserer Gotts diensten nit bedienet ... heußer seindt fast fellig eingefallen, khain hauß ohne Mangl vnd schaden, die mehrern somit sehr merckhlich geschediget, vil miessten gleich samb von neuen auferbauet werden.

Summa am Gebeu ist der Statt Hall schaden ervolgt, welcher niemals mer ersezt, vnd allen Ansechen nach es nimer mer Zu den alten Stand wirdt gebracht werden. Ob nun zwar auch daß liebe Gottshauß in solchem elend: vnd erbarmlichen Standt begriffen, vnd derentwegen 


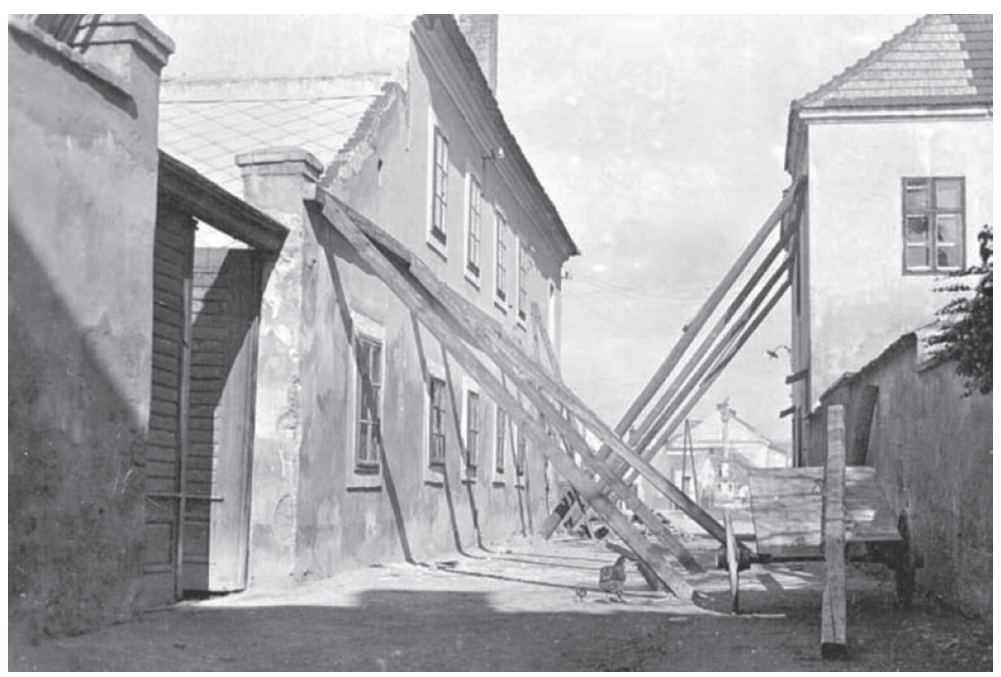

Fig. 6 The picture shows, as an example, houses in Schwadorf in the Vienna Basin supported by wooden struts after the earthquake of October 8th, 1927. The Schwadorf earthquake had a similar epicentral intensity like the 1670 quake in Hall in Tirol.Photo: Archive ZAMG

biß zu dessen reparierung die Gottsdienst, vnd tägliche h: meßopfer grosse Sorg, vnd gefahr nit khinden darinnen gehalten, vnd frequentiert werden, so wirdet man doch eusßersten vnd möglichsten fleis $\beta$ vnd miehe anwenden, damit ehist widerumb geholffen, vnd wegen der Gottsdienst, vnd andern es zu den alten Stand gebracht werde ..."

\subsection{The effects of the earthquake in Innsbruck}

Even today, a mostly unknown inscription in Innsbruck on the so-called "Goldenes Dachl" (Golden Roof) reminds one of the big quake on July 17th, 1670. The inscription, attached in 1671 , is written in the form of a chronogram and reports of the many earthquakes (foreshocks, main shock, aftershocks) of the last year (1670/1671) and of the restoration work after the great earthquake of 1670 (Fig. 7a, b).

The Mayor and Council in Innsbruck wrote a letter on July 23rd, 1670, to the Upper Austrian Hofkammer:

"Demnach diser tagen vermitl $\beta$ des gro $\beta$ entstandenen Erdt Pidnen ain guet Thail der Rinckh Mauer hinter der Pfarrkhirchen in Vnnsers Herrn Dechants Vnnd Statt Pfarrers Garten ein gefallen, auch sonsten dergestalten Paufellig, daß wan man nit Vneinstellige reparation Vornemen würde, die Vbrige was steende Maur auch ... zu Grundt fallen mieste ..." (StAI, Ratsprotokoll 1670, p. 263v.)

The earthquake damaged not only the ring wall in Innsbruck, but also numerous sacred and profane buildings. Among other contemporary sources, a very precise description of damages in Innsbruck was written by an anonymous author on behalf of Anna de' Medici von Toscana, widow of Ferdinand Karl, Archduke of Tyrol "auf genedigsten willen und bevelch der durchleuchtigisten fürstin ..." This source serves as a good basis for damage estimation in Innsbruck. Originally he describes the loud noise that could be heard during the earthquake: "Es war albereit zwischen den 16: und 17: Heymonat die mitternacht fürüber und nach zway uhrn ungevähr ein viertlstund vorbey... Nemblich vernamme mann, ... gleich als khäme von weiten ein saussender wündt mit grossen getös - etliche vergleichen dis saussen, als hetten 30 zusam- 

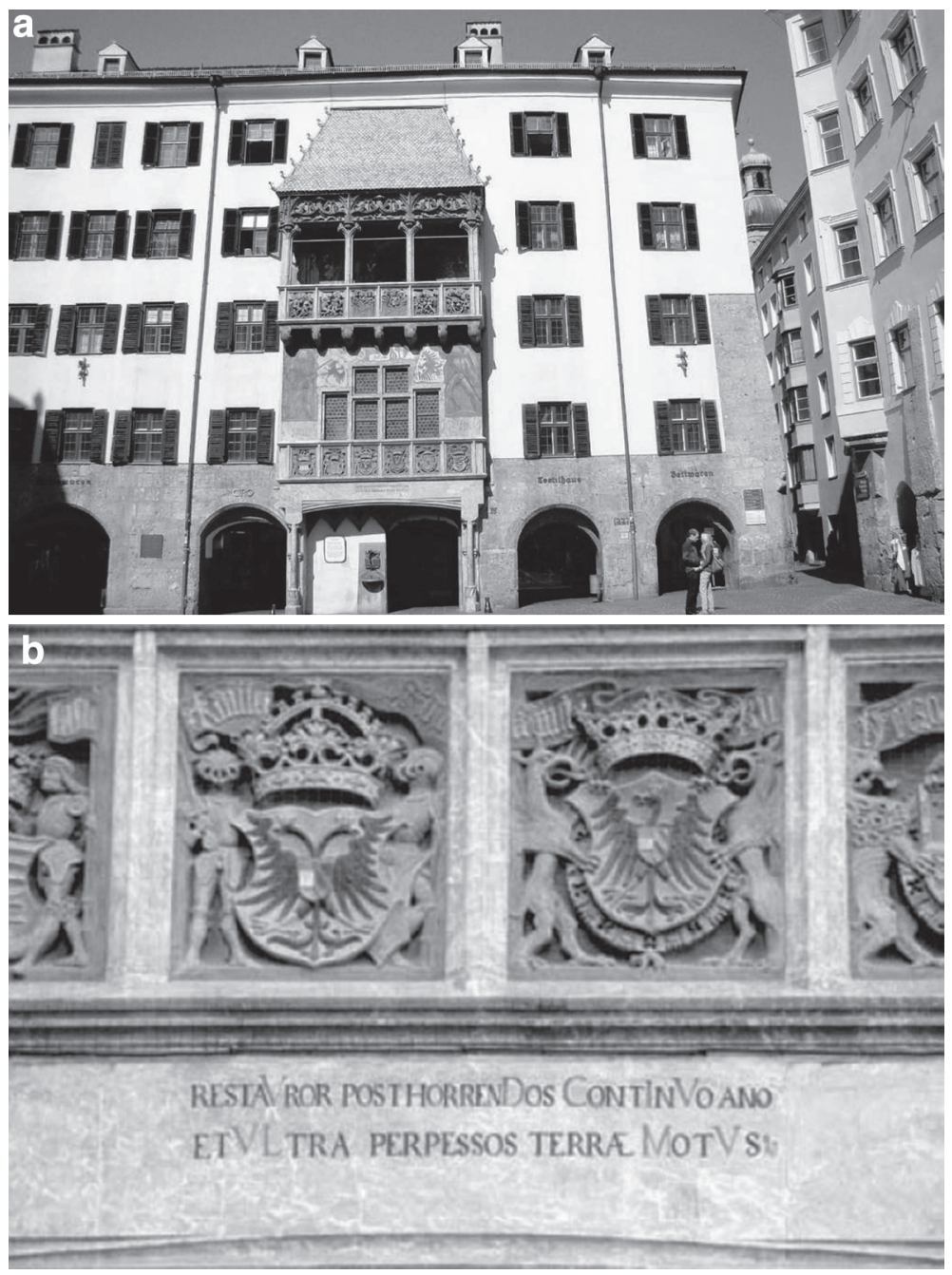

Fig. 7 a, b The inscription was placed at the "Goldenes Dachl" in 1671 and reminds of the restoration work after the earthquake of 1670 in the form of a chronogramm: restaVror post horrenDos ContInVo ano et VLtra perpessos terrae MotVs $(5+500+100+1+5+5+50+1,000+5=1671)$. Translation: I will be re-created after the terrible earthquakes, which were suffered continuously in this year and later. Photo: Ch. Hammerl

men gebundene kazen zugleich erbärmlich geschryen ..." (TLMF, Dipauliana 1080/2, 1670, pp. $2 \mathrm{v}$.-2r.). The noise was almost as loud as the yelling of 30 cats bound together, he said.

It is reported that the rooms were shaking, the wooden beams began to crack, the windows rattled and plaster and pictures fell from the walls. Furthermore, ornaments fell from the cornices and arches suffered damage. In some churches bells rang on their own and several dozen chimneys collapsed from the roofs. The author of the report mentioned at the same time that it was difficult to find one house without a crack, but he realized that many of the cracks had existed before the earthquake occurred, which is a very important consideration in order to assess damage. "... die häuser sich von grundt auf gleichsamb über sich höben und bey etwa vier oder 5 gueten Vatter-Unser lang unbeschreiblich erschüttert zu werden, mit so 
mächtigen gewalt, das khain haus leicht zu Ynsprugg zu finden ohne riss, ohne spalt, ohne anderen schaden ... vil solche riss schon alt und vermuetlich noch von dem grossen erdbiden, den dises land im jahr 1572: laider empfunden, hergeriert habe" (TLMF, Dipauliana 1080/2, 1670, p. 3r.). Also interesting is the following remark, “... das khein mensch nit so alt in disen Tyrolischen ländern ist (denen gleichwol die erdbidem sonst nit gar selzamb), welcher gleichen jammer iemahlen erfahren ..." (TLMF, Dipauliana 1080/2, 1670, p. 3r.). 340 years later, within modern disaster research, H. Tiedemann (1992) formulated this line of thought similarly: "Human memory is, fortunately and unfortunately, shorter than the return period of most disasters."

Among the damaged buildings, the anonymous author mentions the parish church St. Jakob, where a statue of the apostle Jacob collapsed from the church rooftop "... wie dass stainerne bild des grossen heiligen apostels von der obristen spitzen des kirchen tachs auf das stainerne pflaster herabgeworfen ..." (TLMF, Dipauliana 1080/2, 1670, p. 3v.), the Court church, where the tower was damaged "der kirchen thurn also erschittet, das iro herrliches helles gloggen geleith lange zeit nit sicher ohne neue des thurns bevestigung mag angezogen werden ..." (TLMF, Dipauliana 1080/2, 1670, p. 3v.) and the Jesuit's church, where the cupola suffered damage. The other churches showed cracks, but most of them did not suffer any serious damage.

On September 7th, 1670, the dean and pastor Caspar Schwarz reported on the earthquake of July 17th, 1670, to the Episcopal consistory in Brixen. He estimated the damage to the parish church St. Jakob indeed to be low, but respected people's fear of aftershocks. He also mentioned the risk of a panic situation while celebrating Mass (Felmayer et al. 1986, p. 509). To repair the damage of the parish church, 700 florin were needed, of which 400 florins were covered solely from funds of the St. Barbara Brotherhood. The approval of the Ordinariate in Brixen was therefore necessary (Felmayer et al. 1986, p. 510).

Even the Franciscan monastery suffered damage from the earthquake; three chimneys collapsed and many vaults were destroyed. The chronicler noticed in the Convention protocol "... ita, ut deiecerit tres caminos, multos fornices rimaverit, et destruxerit." (Ruggenthaler 2005).

\subsection{Other effects caused by the earthquake in the damage area}

The church of the Franciscan monastery in Schwaz was damaged. The chronicler of the monastery reported stones fallen out of the ceiling of the church and the bells ringing on their own: "Ein fürchterliches Erdbeben begann circa um 2 Uhr nachts und dauerte 5 Vater unser und Ave Maria. Steine fielen von der Kirchendecke und ein Teil des vorderen Dachreiters (Glockentürmchen) fiel herunter vor das Hauptportal der Klosterkirche. Die Kirchenglocken begannen durch die Erschütterungen von allein an zu läuten.” (Ruggenthaler 2005).

After the S. Georgenberger Chronicle also Kolsass and Vomp have suffered from the earthquake. The Dreifache Chronik der Stadt Hall reported another three earthquake victims, “... Zu Thaur (DAI, Pfarrarchiv Thaur, Totenbuch III 1661-1729) seind Zwoh weibspersohnen, und Zu Milss (DAI, Pfarrarchiv Mils bei Hall, Tauf-, Trau- und Sterbebuch 16681703) eine erschlagen worden."

In the register of baptisms, weddings and deaths in the Parish of Mils, an earthquake on July 17 th, 1670, is listed, but there is no evidence of an earthquake victim.

Ferdinand Lechleitner, pastor of Absam, describes in March 1837 the impact of the quake on the Church of St. Magdalena in Halltal. Due to the shaking it was necessary to hold together the walls of the church tower with iron cramps: “... Das Hallthal, oder vielmehr St. Magdalena, wird von einer einzigen Familie bewohnt, welche sich im Meßnerhause aufhält. Das Kirchlein von gottischer Bauart samt Thurm, wurde durch den Erdbeben am 17 July 
1670 sehr stark beschädigt, so, daß es geschleidert werden mußte” (Erzdiözese Brixen, Konsistorialakten, Absam).

The Würtenbergersche Wochen-Protokolle (1660-1689) reported that in Hall and Absam churches and towers were damaged and eight people were killed "... zu Hall und Absam die kirchen und thurnen gross geschädigt, auch 8 personen erschlagen wurden”.

In a letter (Erzdiözese Brixen: Konsistorialakten, Ortsmappe Thaur, 1670) from August 16th, 1670, to the President of the Consistory and to the councils in Brixen the pastor of Thaur, Matheus Obrist, writes among other things of the severe damage to the chapel of the residence Fritzenheim in Fritzens:

“... der andere ware datiert den 1 July, abermahl mit genedigen beuelch auf geführte Clag herren Marthin Rämbs (?) Pfarrer zu Paumbkhirchen, die Capelle zu Frizhaimb zu visitiren, vnd daryber ain Guetachten zu yberschickhen. Die Capelle hab ich Zwar Visitiert, aber ... von den Erdbiden ruinierter gefunden, das wenigst daß Gewelben Vellig mueß eingeworffen werden, wie auch ain selbiches bey mier ... geschechen muеß ..." (Erzdiözese Brixen: Konsistorialakten, Ortsmappe Thaur).

\subsection{The effects of the earthquake in the far field}

Information of the far field of the earthquake can be found in the Theatrum Europaeum (1677), founded by Matthäus Merian and published from 1633 to 1738 as a German historical work, for the following places: Regensburg: heavily felt; Donauwörth: heavily felt, bed: swinging motion; Wildungen: the mortar clinks in the pharmacy "hat der Mörser in der Apotecken daselbst hiervon/als wann er gestossen würde/sich hören lassen"; Nürnberg: Dishes fell off the table, Bed: swinging motion; Augsburg: heavily felt; Lindau: felt; Memmingen: felt; Kempten: felt; Leutkirchen: felt; Venedig: felt; Salzburg (Mezger 1692): moderately felt,

The chronicler Wengin Nördlingen reported: On July 7th, (probably old style = July 17, New Style) an earthquake was felt there, but not in all places of the city. "Den 7. Juli [wohl alt. Stils $=17$. Juli $n$. St] liess sich allhier ein Erdbeben verspüren, welches man aber nicht an allen Orten der Stadt verspüret hat." (Von Gümbel 1889).

The Swiss physician and naturalist Johann Jacob Scheuchzer (1718) reported that the quake was felt in St. Gallen, Switzerland, too. He refers to a paper (Haltmeyer 1683) from 1683. Such messages are to be used with restrictions.

\subsection{The effects of the earthquake on the natural environment}

Informative for the correct and full assessment of an earthquake are also the effects on the natural environment, which can be assigned to the 12-part ESI-scale (Environmental Seismic Intensity Scale, also ESI 2007), an intensity scale that was developed by the INQUA (International Union for Quaternary Research).

The estimate for the following descriptions corresponds to the intensity between $7^{\circ}$ and $8^{\circ}$ on the ESI scale, which matches the intensity estimate of $8^{\circ}$ for the epicenter according to the EMS-98.

The impact of the quake on "the natural environment" is described in the Dreifachen Chronik der Stadt Hall for the surroundings of Volders, Baumkirchen and the Zillertal:

"... Ja auch hin und wider die berg Zerrissen und Zerkhloben [Note: rockfall]wie dan under anderen an dem Voldersperg, woh man von dem Dorf Volders in das paad ${ }^{3}$ [Note: Volderwildbad] hinein geeht, ein schrunden oder khlufften [Note: fissure] von 315 khlaffter ${ }^{4}$ lang,

\footnotetext{
3 Mineral spring.

41 Klafter ca. $1.8 \mathrm{~m}$.
} 
und an etlichen orthen einen halben, einen ganzen und auch anderthalbn werckhschuech Praid $\mathrm{Zu}$ sehen. Ingleichen bey Paumkhirchen [Note: Baumkirchen], woh man in das Farbenthall [Note: Farbental] hineingehet, ein andere khlufft von 50 khlaffter lang: wie auch ohn anderen herumligenten Pergen mehrer. In dem Zillerthall soll ein Perg Zersprungen [Note: rockfall] sein und auf einer Almen 30 khühe Zu thott geschlagen, und so geschädiget, die hirten Buben aber sind khurz Zuvor anderstwohin gangen." (Seeböck 1882, p. 313).

After the earthquake, the springs of the spa in Baumkirchen ran dry and St. Anna Chapel suffered severe damage: “... In Baumkirchen das Badwasser seit 17. Juli ausgegangen und das St. Annakirchlein eingestürzt” (Seeböck 1882, p. 323). Significant temporary variations of the water level in wells and/or of the flow-rate of springs are locally recorded from degree VI upward on the ESI-scale. Seldom, small springs may have temporarily run dry would appear from degree VII upward.

In the surroundings of Innsbruck, water turbidity was observed and the flow-rate changed: “... an etlichen brunnen, wie das wasser ganz trieb auss erschitlung und vermengung der erden herrinnte, wie auch das mihlwasser in dem benachbarten dörfflen Mihlen [Note: Mühlau] genant, umb das dritthail mer wasser, als vor dem erdbiden bestendig herfiere..."(TLMF, Dipauliana 1080/2, 1670, fol 2v-3r.).

In a later copy of the Haller Erdbeben-Chronik (TLMF, Dipauliana 931 I), additional locations affected by the quake were reported, e.g. surface fault ruptures and water turbidity: “...vom Wattenberg kommend, einem Patri Societatis erzählet dass ihr mann vor 15 jahren ein haus hoch auf ein berg erbauet, welches sich jetzunder seit dem erdbeben am 17. Juli herum eine kluft eines schuch breit, und etlich klafter in der länge und gleichsamm unergründlich sich sehen lassen und anstatt des klaren wassers, ein trübes schwarzes Wasser herfürquelle, welches alles wahr zu sein sich nachher befunden..."

The effects of the earthquake in the Haller Salzberg are also interesting. It was reported that the miners underground heard a terrible roar, and the ground shook so strongly that they were not able to stand. The earthquake did not cause damage undergound, but rockfalls were reported “... ausswendig aber an underschidlichen Pergen hin und wider grosse stuckh Felsen herunder geworffen ..." (Seeböck 1882, p. 306). This description is consistent with the experience that earthquake effects underground are more minor than at the surface.

Side effects at intensity 8 on the ESI scale are "anomalous waves", which were observed at the river Inn: “... So hatt auch der Ihnn erschröckhlich getobet und gewüthet; hatt den sand von grund auf ubersich geworffen, das das wasser gleichsamb durch die furchen geflossen; die schiff aneinander gestossen, das die Jenige so darinnen waren vermaindten sie rinnen schon darvon, und sie werden alle Zu grund gehen.” (Seeböck 1882, p. 306).

\subsection{Results for the earthquake of July 17th, 1670}

The earthquake on Thursday July 17th, 1670, is well documented by contemporary sources. The epicenter in Hall and an epicentral intensity of 8 degrees on the 12-part EMS-98 could be confirmed. This means, according to this scale, that many people find it difficult to stand. Many houses show large cracks in walls. A few well built ordinary buildings show serious failure of walls, while weak older structures may collapse. The quake killed at least nine persons in Hall and Thaur.

Reports about this earthquake are from the following places: Absam, Augsburg, Baumkirchen, Donauwörth, Farbental, Frankfurt, Fritzens, Hall in Tirol, Innsbruck (Mühlau), Kolsass, Kempten, Leutkirch im Allgäu, Lindau, Mantua, Memmingen, Mils, Nördlingn, Nürnberg, Regensburg, Salzburg, Schwaz, St. Gallen, St. Magdalena im Halltal, Thaur, Venedig, Volders, Volderwildbad, Vomp, Wattenberg, Zillertal. 
Table 2 Macroseismic data 1670 earthquake points (MDPs) of the July 17th,

\begin{tabular}{|c|c|c|c|}
\hline Locality & Long. & Lat. & $\begin{array}{l}\text { Intensity } \\
\text { EMS-98 }\end{array}$ \\
\hline Absam & 11.500 & 47.300 & $\mathrm{D} \stackrel{\wedge}{=} 7-8$ \\
\hline Augsburg & 10.883 & 48.367 & $\mathrm{~F} \triangleq 5$ \\
\hline Baumkirchen & 11.567 & 47.300 & 7 \\
\hline Donauwörth & 10.800 & 48.700 & $\mathrm{~F} \triangleq 4$ \\
\hline Frankfurt & 10.798 & 45.160 & $\mathrm{~F} \stackrel{\wedge}{=} 5$ \\
\hline Fritzens & 11.590 & 47.306 & $\mathrm{D}$ \\
\hline Hall in Tirol & 11.517 & 47.283 & $\mathrm{D} \stackrel{\wedge}{=} 8$ \\
\hline Innsbruck & 11.400 & 47.267 & $\mathrm{D} \triangleq 7-8$ \\
\hline Kolsass & 11.633 & 47.283 & $\mathrm{~F} \stackrel{\wedge}{=}-4$ \\
\hline Kempten & 10.317 & 47.717 & $\mathrm{~F} \triangleq 3-4$ \\
\hline Leutkirch im Allgäu & 10.022 & 47.826 & $\mathrm{~F} \stackrel{\wedge}{=}-4$ \\
\hline Lindau & 9.683 & 47.550 & $\mathrm{~F} \stackrel{\wedge}{=}-4$ \\
\hline Mantova & 10.798 & 45.160 & $\mathrm{~F}$ \\
\hline Memmingen & 10.167 & 47.983 & $\mathrm{~F} \triangleq 3-4$ \\
\hline Mils & 11.529 & 47.294 & $\mathrm{D} \stackrel{\wedge}{=}-8$ \\
\hline Nördlingen & 10.498 & 48.850 & $\mathrm{~F}$ \\
\hline Nürnberg & 11.083 & 49.450 & $\mathrm{~F} \stackrel{\wedge}{=} 5$ \\
\hline Regensburg & 12.100 & 49.017 & $\mathrm{~F} \triangleq 3-4$ \\
\hline Salzburg & 13.033 & 47.800 & $\mathrm{~F} \triangleq 3$ \\
\hline Schwaz & 11.700 & 47.333 & $\mathrm{D} \triangleq 6$ \\
\hline St.Gallen & 9.400 & 47.467 & $\mathrm{~F} \triangleq 3-4$ \\
\hline St.Magdalena im Halltal & 11.493 & 47.327 & HD \\
\hline Thaur & 11.472 & 47.295 & $\mathrm{D} \stackrel{\wedge}{=} 7-8$ \\
\hline Vellenberg (Götzens) & 11.313 & 47.242 & $\mathrm{D}$ \\
\hline Venezia & 12.327 & 45.439 & $\mathrm{~F} \stackrel{\wedge}{=}-4$ \\
\hline Volders & 11.567 & 47.283 & $\mathrm{~F} \triangleq 7$ \\
\hline Volderwildbad & 11.561 & 47.251 & F-D \\
\hline Vomp & 11.683 & 47.333 & $\mathrm{~F} \triangleq 3-4$ \\
\hline Wattenberg & 11.600 & 47.283 & $\mathrm{D} \triangleq 6$ \\
\hline
\end{tabular}

The quake occurred at 1:00 UTC. The epicentral intensity is estimated as $8^{\circ}$ EMS-98 and the epicenter is determined as being in Hall in Tirol. Aftershocks lasting more than 50 days were reported (Table 2).

\section{The earthquake of December 22nd, 1689}

\subsection{Damage in Innsbruck}

The earthquake of December 22nd, 1689, is one of the strongest known earthquakes in Tyrol. 


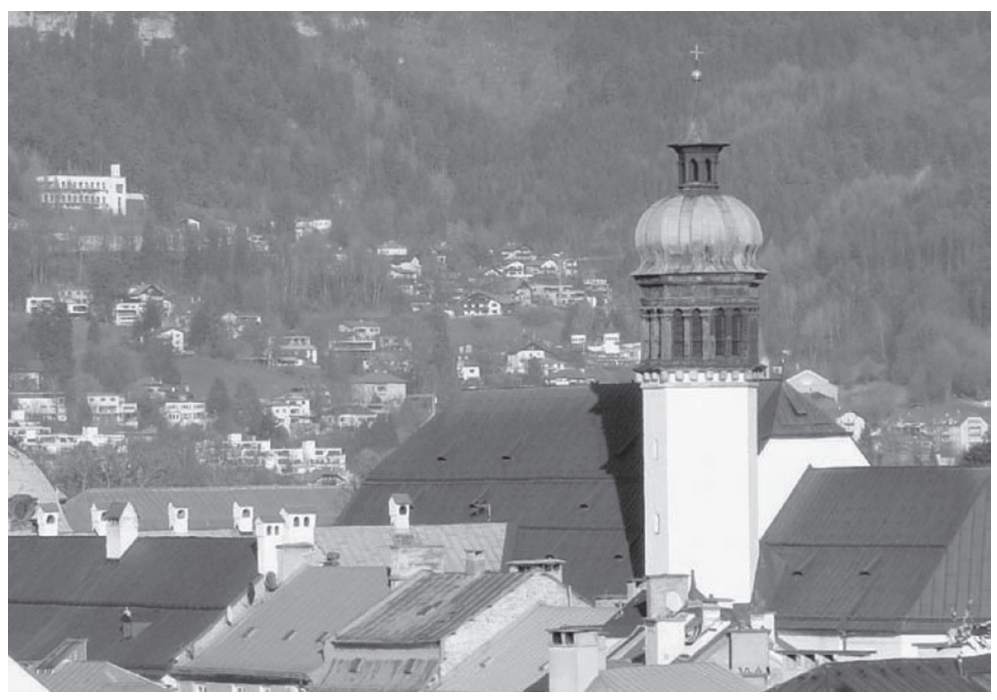

Fig. 8 During the restoration work of the Innsbrucker Hofkirche the globe-shaped decoration at the steeple was analysed. Six contemporary texts were found, five texts reported about the earthquake of December 22nd, 1689 in Innsbruck. Municipal archive Innsbruck. Photo: Ch. Hammerl

The Innsbruck Council minutes reported that after 2 in the morning there was a horrible earthquake, the duration was as long as one Ave Maria and that in the city, even along the moat from the gate Pickentor up to the Franciscans and the hospital church, no monastery, church or private house remained undamaged "Den 22 Decembris A[nn]o etc 1689. in der fruehe etwa ain Halb viertl nach $2 \mathrm{Vhr}$, also vmb Miternacht, an ainem Pfinztag [Note: Thursday], Ist ain Erschrockhlicher Erdtpiden vber die Statt Ynsprugg khomen, so etwo ain Vatter vnnser vnd Aue Maria lanng gewertig, aber solliche grausame stoß vnd Schittler geben ... sambt allen Kirchen vnd Clösstern khein hau $\beta$ vnbeschädiget verbliben ..." The author of the minutes also reported that he could describe neither the misery and the shock of the inhabitants in the middle of such a cold winter night nor the destruction of some houses (StAI, Ratsprotokoll 1689, pp. 71v-72r.). The earthquake would keep the Council busy for a long time.

Also, the Theatrum Europaeum (1698) reported from the dramatic event especially that the Archduke's residence was shaken heavily, and that not a single building remained undamaged "... so haben sich auch alle die Hof = Damen/etliche ohne Schuheletliche in bloßen linnen dahin begeben/welchen viele andere Manns = und Weibs = Personen aus der Stadt gefolget/und sind in selbiger viel Personen von denen eingefallenen Häusern bedecket worden und todt geblieben: Doch sind den andern Tag unterschiedliche Halb = Todte wieder herfür gekrochen/weil aber die Erschütterungen noch angehalten/so sind die meisten Einwohner aus der Stadt in die nächst gelegene Dörffer/oder ausserhalb der Stadt in die Ställe und kleine Häuser entwichen ...” The city tower also suffered damage.

During the restoration of the Innsbrucker Hofkirche (Franciscan Church), the golden globe-shaped decoration at the steeple (Fig. 8) was analysed. Six contemporary texts (StAI: Sammelakt 1/4) were found, five of which reported about the earthquake of 22.12.1689 in Innsbruck (Hye 1981).

Furthermore, a copy of a contemporary letter (StAI: Sammelakt 1/3) from the Franciscan friar Justus Redn was enclosed. From these documents we learn that e.g. “... von Tufft gemaurter, rott geförbter Spizthurn ...” the tower of St. Jakob was taken down after the 
earthquake. The damage to the presbytery, the residential houses of the clergymen and the hospital was also significant; costs were estimated at 20,000 florins. The earthquakes of 1670 and 1689 thus marked the end of the late-Gothic church of St. Jakob, and in 1717 the church was demolished and replaced by a baroque building, which was consecrated in 1724 .

At the Hofburg "Der alten Burckh gegen dem Rennplaz [Note: Rennweg]", the rondels were severely damaged and had to be held together with iron cramps. The Franciscan church suffered great damage “... hat es der Kirchen, die von alter zuegespizt aufsteigendt gehabte Seitengewölben [Note: aisles]dergestalten zusamb schadthafft geschoben, das sye haben abgetragen und von neuen durchgehent geschleidert, gewölbt und außgearbeit worden ..."

The bell tower had to be taken down to the belfry.

Three days after the quake, the former curator of the North Tyrolean Franciscan Order, Father Justus Redn, wrote in the most beautiful "dog Latin" to the Provincial Father Adrian Hueppher, inter alia, about the damage to the monastery (Archiv der Tiroler Franziskanerprovinz Hall in Tirol: Akten, 6/1-R94, 1689): "In monasterio nostro seindt alle schidmäurlen creutzweis gespaltet; die gebrochen Stiegen ad superius dormitorium sehr debilitiert, camini ex maiori parte aut diruti aut succisi, fornaces mehrentheils gantz ruiniert oder abgelöset." He reported e.g. damage to the stairs and to the stoves, and in the Franciscan church the lateral altars had been completely destroyed. "In ecclesia nostra seindt die zwei laterales ab altari B. V. Mariae usque ad S. Hyacinthum ${ }^{5}$ gantz wulnerient, adeo, dass alle zwei ambulacra alldorten verschlossen seindt und speciatim die thür versus perstyllium, allwo ex fornice ein nambhaffter Bruch heraus ist ..." Additionally the nave, he said, was damaged, but less so than the aisles "... hat es zwar auch schwere Difficulteten besonders infra altare $C$. Paschalis. ${ }^{6}$, doch nit so schwere als in fornicibus lateralibus." In the upper choir it was particularly dangerous, but fortunately the earthquake did not occur in the early morning “... wegen der gradt. ${ }^{7}$ wan solche tempore matutini gefallen werden, wurden gewißlich solche ohne erschröckhlichen effect und etwelchen totschlag nit vorbeygangen sein". Fortunately, the quake occurred during the night, when the church was empty, otherwise it was feared there would have been heavy casualties. Justus Redn also said that the source of the quake was at Zirl.

In the parchments of the above-mentioned golden globe-shaped decoration of the tower, the damage to the Jesuit church is described as heavy, namely that the walls of the building moved apart, and thus endangered the stability of the dome. It was feared, if further shocks occurred, that the church would collapse "... alles zu ainen Stainhauffen zusamben gefallen". The "... alt und neu Colegio" suffered only little damage. For the repair of the church and the Kolleg, 130 centner of iron were necessary.

At the Capuchin Church and the Capuchin monastery “... als ein niders Gepey ...”, comparatively little damage was reported. The repair costs amounted to 500 florin, which has been confirmed by Father Justus Redn: “... vorbei an der Kapuzinerkirche, die nicht sonderlich zerstört worden war ..."

The monastery church tower of the "Versperrtes Kloster" of the Servite Order partially collapsed due to the quake. The "Regelhaus" was also damaged (StAI, Sammelakt 1/4).

The parish church of Sts. Pirmin, Rochus and Sebastian (Dreiheiligenstraße) suffered severe structural damage caused by the quake. Brick layer Heinrich Renn took down the church's vault and built, for cost reasons, a new one made of wood (Fischnaler 1934).

5 The altar of St. Hyacinth stood against the wall of the left side of the aisle.

6 The altar of the saint C. Paschalis was formerly directly behind the mausoleum.

7 Ribs of the vault. 
The Siebenkapellenkirche (Kapuzinergasse 39) was severely damaged by multiple natural disasters, especially by the earthquake of 1689 , and was therefore dilapidated and taken down (Felmayer et al. 1986). The parish church of Mariahilf (Dr. Sigismund Epp-Weg 1) suffered severe damage (TLA, Abteilung Mariahilf 1692).

The old Government Building "Altes Regierungsgebäude" (Herzog-Friedrich-Str. 3) was renovated completely. The reconstruction totalling 16,000 florin was very expensive. “... ist die völlige vordere Seithen in der Statt biß auf den Grundt abgetragen und von neuen aufgefierth, auch sonsten grosse Verenderung und Abtragung der Hechen in ainder gleichen vorgenomben, welcher Uncosten sich biß 16.000 fl. erströckhet hat ..." 85 centner of iron were used for cramps (StAI, Sammelakt 1/4).

Contrary to the earthquakes of 1572 and 1670, the so-called "Goldenes Dachl" was not damaged "... zwar den Gulden Tächl nicht geschadet ..." but the walls of the "Neuhof" had to be supported. For the cramps, 74 centner of iron were used, and the costs amounted to 8,000 florins.

In 1689, the "Landhaus" in the "Neustadt" was damaged by the earthquake and a fire (Maria Theresien-Straße no. 43 Altes Landhaus).

Built in 1679/1680 on behalf of Count Otto Hans Fugger von Kirchberg-Weissenhorn according to plans by the court architect Johann Gumpp, the neighbouring building, the Palais Fugger-taxis (Maria Theresien-Straße No. 45), suffered damage from the quake as well.

Furthermore, at the inns Goldener Hirsch (Seilergasse 9) and Roter Adler (Seilergasse no. 4 and 6) earthquake damage was identified and quake victims were reported “... alda 7 Persohnen, 3 Khinder todt gebliben ..." (StAI, Sammelakt 1/4). In the register of deaths of St. Jakob it is noted that 11 persons were killed by the earthquake "... Den 22 dito seint von Erdbiden Erschlagen worden 11 Persohnen ...” (DAI: Innsbruck-St. Jakob Dompfarre, Sterbebuch VII 1672-1710). The houses in the Kiebach-Seilergasse were so damaged that they had to be rebuilt "... sie nothwendig völlig abzutragen und von neuen aufzufiehren". All needed to be rebuilt, Father Justus Redn wrote in his letter to the Provincial Father Adrian Hueppher from 25.12.1689 (Archiv der Tiroler Franziskanerprovinz Hall in Tirol: Akten, 6/1-R94 1689). Hueppher also mentioned damage to the churches in Hötting, Allerheiligen, Mühlau and Arzl.

\subsection{Damage in Hall in Tirol}

New contemporary sources found mainly in the Haller City Archive were evaluated to describe the effects of the earthquake in greater detail.

The report to the Gubernator of Tyrol, Karl V. Leopold, Duke of Lorraine and Bar, describes the damage caused by the earthquake “... was etwa durch dieser entstandne grausame Erpidmen, in, vnd auser der Statt Halln, ... an heisern, maurwerh, und sonstn für schaden erfolgt ...” (STAH, Miscellaneen, Erdbebenschaden 1689) (Fig. 9). It was reported that nearly all chimneys in Hall either completely or partially collapsed, hence a greater fire risk reigned in the aftermath “... fast alle Camin in der ganzen Statt, eindtweders völlig, oder zum thaill eingefallen, oder zerspalten, abgesezt, vnd sonsten der gestalten ruiniert, das mit ein Feyrung derselbigen, durchgehendt grosse Feuersgefahr...". Due to the severe cold, the order to repair the chimneys was given out because many poor people had neither food nor clothes "... ville Arme leith, weliche weder narung noch noturffige Claidung haben ...". The presence at the fire station was intensified.

The buildings in Hall in Tirol were restored after the earthquake of 1670. If this had not taken place, the author of the report said, all buildings would have collapsed "... alle 


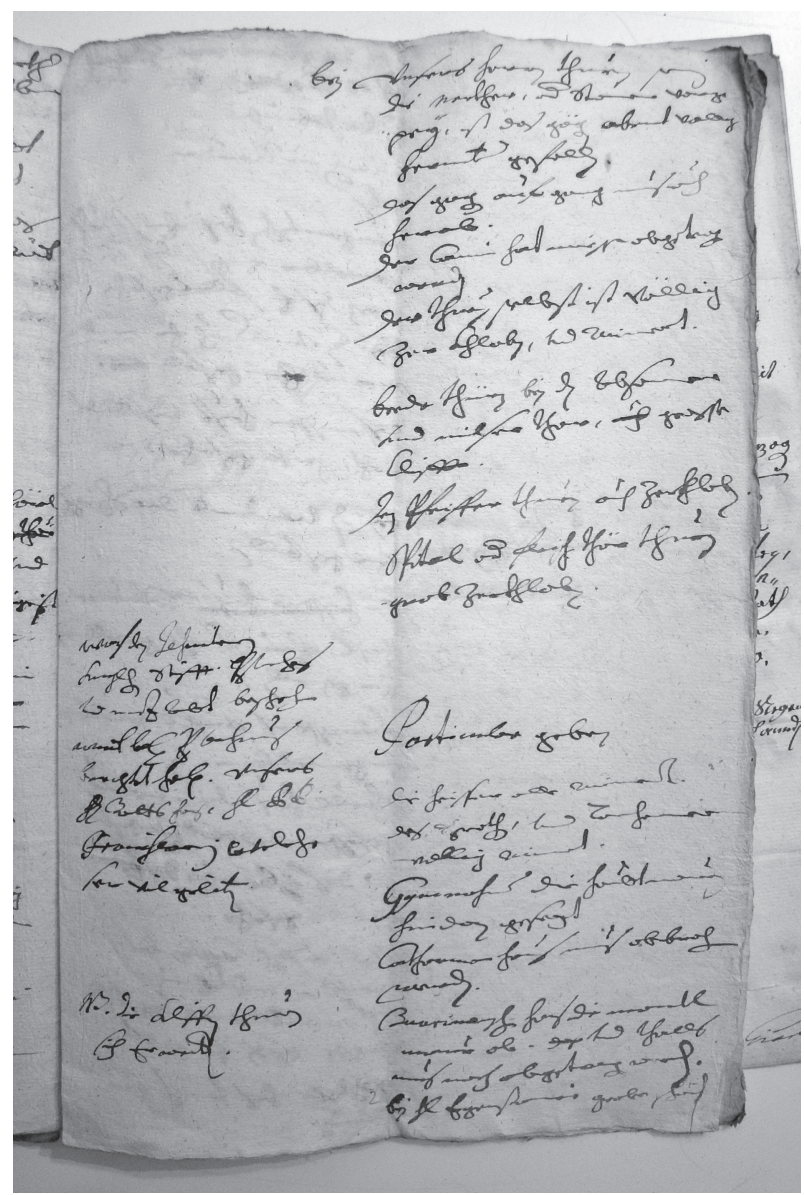

Fig. 9 The report to the Gubernator of Tyrol, Karl V. Leopold, Duke of Lorraine and Bar, describes the damage caused by the earthquake on December 22nd, 1689. Municipal archive Hall in Tirol, Miscellaneen. Photo: Ch. Hammerl

heiser vnd gebei völlig yber den haufen geworfen sein ..." This statement is important for the damage assessment. Below, the damages in Hall are listed partly and shortened. The information stems from the above mentioned report, unless otherwise noted.

Absamer und Milser gate: big cracks; Eugenstraße: Nr. 2: collapsed vault, Nr. 8 damage; Gymnasium: heavy damage, house must be demolished; Heillig Geist hospital/church: heavy damage; Heillig Geist hospital: heavy damage (big cracks); Tower Herrenturm (Thaurertor): heavy damage; Kurzer Graben: Nr. 8 mantlet wall collapsed; Mustergasse: Nr. 3: heavy damage; Tower Pfeifferturm ${ }^{8}$ : damage; Rosengasse: Nr. 3 big cracks; Salvatorgasse: Nr. 4/6/8 (TLMF, FB 4177, Vermischte Nachrichten vom k. k. Salzberg zu Hall im Ynnthall, 1777): three houses collapsed, 9 persons killed “... hat ein Erdbiden zu Hall 3 Häusser eingeschmissen und 9 Persohnen erschlagen. an diesen Blatz ist hienach dass Stadt Breyhauss gebauet worden ..."; Salvatorgasse: Nr. 5 connected with Schmiedgasse: Nr. 4 damage to the vaults; Schlossergasse: Nr. 12 mantlet wall collapsed; Schmiedgasse: Nr. 13 collapse of

8 Prison at the gate "Schergentor". 
one vault; Schmiedturm: heavy damage; Schmiedtorgasse: Nr. 2 inn Gasthof zum Wilden Mann, gable collapsed, one mantlet wall collapsed; tower Spital oder Fleischtor Turm: heavy damage .

St. Nikolaus: damage, cracks; Stadtgraben Nr. 2/Schmiedgasse Nr. 20: damage, mantlet wall collapsed; Unterer Stadtplatz: Nr. 10 roof damaged; Nr. 13, former name also Spitalsplatz: heavy damage; Nr. 4 kitchen collapsed; Veits Kirchl: heavy damage; Wolfgangskapelle: damage; "Zwinger” dungeon near Schergentor (former South gate): damage; between the towers Schmied- und Herrenturm: town wall collapsed.

Johann Capistrano Würtenberger (TLMF: FB 4172: Würtenbergische Wochen-Protokolle 1689), an intern from the Salzberg in Hall, reported that the Church of St. Magdalena im Halltal had been damaged again “... Der erdpidem hat in Hallthall in der Kirchen und in Messner hauss grossen schaden getan ...”

Only one place in the far field of the quake, Augsburg in Germany, is mentioned in Theatrum Europaeum (1698): “... Auch ist dieses Erdbeben zu Augspurg und mehren Orten/wie wohl mit fast weniger Würckung/gespühret worden."

This quake caused at least 11 deaths in Hall (Pfarrarchiv Hall in Tirol: Totenbuch 18841705).

In the convent protocol of the Franciscan monastery in Schwaz (Ruggenthaler 2005), the following entry was found: "On December 22nd, 1689 at half past two at night in Schwaz, a big earthquake was felt, it lasted about three Pater Noster. Thank God there was only little damage to buildings in Schwaz ..."

\subsection{Results for the earthquake of December 22nd, 1689}

The information on the quake shows that the damage in Innsbruck and Hall was similar to damage result from the quake in 1670. It must be stressed, however, that the buildings had already been damaged by the earthquake of 1670 . On the other hand, many buildings were, due to the previous repair work, in a better condition than before 1670 .

This quake also resulted in multiple fatalities, not only at least eleven in Hall but also eleven in Innsbruck.

The epicentral intensity was estimated with $7^{\circ}-8^{\circ}$ EMS-98, i.e. according to this scale, $7^{\circ}$ means most people are frightened and run outdoors. Furniture is shifted and objects fall from shelves in large numbers. Many well built ordinary buildings suffer moderate damage: small cracks in walls, fall of plaster, parts of chimneys fall down; older buildings may show large cracks in walls and failure of fill-in walls. Degree 8 means many people find it difficult to stand. Many houses have large cracks in walls. A few well-built ordinary buildings show serious failure of walls, while weak older structures may collapse.

Reports about this earthquake are known from the following cities: Augsburg, Hall in Tirol (with St. Magdalena in Halltal), Innsbruck (Allerheiligen, Arzl, Hötting and Mühlau) and Schwaz (Table 3).

\section{Conclusion}

Within the INTERREG IV project HAREIA, one of the examined earthquakes, namely that of 1571 , could be identified as a fake.

The epicentral intensity of the 1572 earthquake was downgraded due to the information of the sources.

Several new sources have been found in the archives for the earthquakes of 1670 and 1689. 
Table 3 Macroseismic data points (MDPs) of the December 22nd, 1689 earthquake

\begin{tabular}{llll}
\hline Locality & Long. & Lat. & $\begin{array}{l}\text { Intensity } \\
\text { EMS-98 }\end{array}$ \\
\hline Absam & 11.500 & 47.300 & $\mathrm{HD}$ \\
Augsburg & 10.883 & 48.367 & $\mathrm{~F} \bumpeq 3-4$ \\
Hall in Tirol & 11.517 & 47.283 & 7 \\
Hippach & 11.866 & 47.204 & $\mathrm{HD}$ \\
Innsbruck & 11.400 & 47.267 & $7-8$ \\
Schwaz & 11.700 & 47.333 & $5-6$ \\
St.Magdalena im Halltal & 11.493 & 47.327 & $\mathrm{D}$ \\
Vellenberg & 11.313 & 47.242 & $\mathrm{D}$ \\
\hline
\end{tabular}

A contemporary source from the city archive in Hall in Tirol contained unknown information for the 1689 quake. This source describes the damage of the earthquake of 1689 in Hall, which leads to much more detailed knowledge of its impact on the city.

Although the events discussed occur rarely, earthquakes of such intensity can cause personal suffering and huge economic losses. It is therefore important to investigate the effects of historical earthquakes according to the state of the art to improve the knowledge of past damaging earthquakes.

An important result of this study is, among other things, that for the first time macroseismic data points are available, which allows transparency in the assessment of the new parameters and contributes to the seismic history of single locations.

\section{References}

Archiv der Tiroler Franziskanerprovinz Hall in Tirol (1689) Akten, 6/1-R94 loser Akt. Brief P. Justus Redn an Provinzial P. Adrian Hueppher vom 25

Archiv der Tiroler Franziskanerprovinz Hall in Tirol: Konventprotokoll Innsbruck Cod. 61 (1653-1748) fol 29

Archiv der Tiroler Franziskanerprovinz Hall in Tirol: Konventsprotokoll Schwaz I, 223. S. a. Ruggenthaler P O OFM (2005) Erdbeben im Tiroler Inntal im 17. und 18. Jahrhundert. Tiroler Heimatblätter 80, H. 1. Innsbruck

Brixen-Ordensarchiv (1670) Schuber Innsbruck III, St. Jakob III, Mappe IX, Nr. 2. Bericht des Dekans und Stadtpfarrers Caspar Schwarz über das Erdbeben vom 17. Juli 1670 an das bischöfliche Konsistorium in Brixen. In: Felmayr J (ed) (1981) Die Kunstdenkmäler der Stadt Innsbruck. Tl. 2. Die profanen Kunstdenkmäler der Stadt Innsbruck außerhalb der Altstadt. Österreichische Kunsttopographie. vol 45. Wien, Vienna

Brixen-Ordensarchiv (1678):Schuber Innsbruck, St. Jakob II, Mappe VII, Nr. 5 sowie Mappe III, Nr. 2 und Nr. 4. Kommission unter dem Vorsitz des Dekans von Thaur über die zusätzlich zu den Eigenmitteln von St. Jakob benötigten Subventionen zur Behebung der Erdbebenschäden von 1670. In: Felmayr J (ed) (1981) Die Kunstdenkmäler der Stadt Innsbruck. Tl. 2. Die profanen Kunstdenkmäler der Stadt Innsbruck außerhalb der Altstadt. Österreichische Kunsttopographie. vol 45. Wien, Vienna

DAI = Diözesanarchiv Innsbruck: Innsbruck - St. Jakob Dompfarre, Sterbebuch VII 1672-1710 (Film Nr. 992) fol 36 (bzw 264)

DAI = Diözesanarchiv Innsbruck: Pfarrarchiv Mils bei Hall, Tauf-, Trau- und Sterbebuch 1668-1703 (Film Nr. 632)

Erzdiözese Brixen: Konsistorialakten, Absam. Topographie der Pfarre Absam

Erzdiözese Brixen: Konsistorialakten, Ortsmappe Hall Pfarre VIII, Brief des Haller Pfarrers Stephan Gifl an das Konsistorium in Brixen, Hall, 26. Juli 1670

Erzdiözese Brixen: (1670) Konsistorialakten, Ortsmappe Thaur. Brief des Pfarrers von Thaur Matheus Obrist an den Präsidenten des Konsistoriums und die Räte in Brixen. Thaur, 16.8.1670 
Erzdiözese Brixen (1572) Konsistorialakten, Topographie Dekanat Hall. Brief des Melchior Hannibal, Freiherr von Wolkenstein an JOHANN VI. Thomas von Spaur, Koadjutor und Bischof in Brixen, 10.2.1572

Egger F (1949) Aus Halls vergangenen Zeiten. Hektographiertes Manuskript, Hall in Tirol 227 [StAH = Stadtarchiv Hall in Tirol]

Felmayer J, Oettinger K, Oettinger R, Scheicher e, Arnold-Öttl H, Frenzel M (ed) (1986) Die Kunstdenkmäler der Stadt Innsbruck. Tl. 3: Die Hofbauten. Österreichische Kunsttopographie 47. Wien, Vienna, p 453

Fischnaler K (1934) Innsbrucker Chronik vol 5. Innsbruck

Haltmeyer M (1683) Beschreibung der Eidgnössischen Statt St. Gallen. Gelegenheit, Geschichten und Regiment: wie auch des Lebens Hrn von Watt (Joach.Vadiani) gewes. Burgem. daselbst, p 658

Humberdrotz R (ed) (1956), Das Tagebuch des Johann Sigmund von Rost zu Kehlburg und Aufhofen. Pfleger von St. Michaelsburg (St. Lorenzen) und Amtmann des Haller Damenstifts in der Herrschaft Lienz 1653-1729. Schlern-Schriften 114. Innsbruck, pp 29-30

Hye F-H (1981) Der Inhalt der Turmkugel der Innsbrucker Hofkirche und das Erdbeben am 22. Dezember 1689. Tiroler Heimatblätter 56:44-53

ESI scale (2014) http://www.isprambiente.gov.it/files/progetti/inqua/esi-2007-synoptic-table-of-intensitydegrees.pdf. Accessed 15 Sept 2014

Keferstein Ch (1826) Versuch eines chronologischen Verzeichnisses der Erdbeben und vulkanischen Ausbrüche seit Anfang unserer Zeitrechnung. In: Keferstein Ch (ed) Teutschland, geognostisch-geologisch dargestellt. Eine Zeitschrift, vol 4, 1. Weimar, p 292

Konventprotokoll Schwaz I, 162-163. In: Ruggenthaler P O OFM (2005) Erdbeben im Tiroler Inntal im 17. und 18. Jahrhundert. Tiroler Heimatblätter 80, H. 1. Innsbruck

Mezger P J (1692) Geschichte Salzburgs, Salzburg

Moser H (1989) Hall in Tirol - Entwicklung und Erneuerung der Altstadt. Hall in Tirol

Nachricht verifiziert im DAI: Pfarrarchiv Thaur, Totenbuch III 1661-1729 (Film Nr. 629) fol 8

Pfarrarchiv Hall in Tirol (1667-1683) Totenbuch

Pfarrarchiv Hall in Tirol: Totenbuch (1684-1705) fol.116-117

Ruggenthaler P O OFM (2005) Erdbeben im Tiroler Inntal im 17. und 18. Jahrhundert. Tiroler Heimatblätter 80, H. 1. Innsbruck

Sandgruber R (1995) Ökonomie und Politik. Österreichische Wirtschaftsgeschichte vom Mittelalter bis zur Gegenwart. In: Wolfram H (ed) Österreichische Geschichte, vol 10. Wien, Vienna, p 585

Scheuchzer J J (1718) Meteorologia et Oryctographia Helvetica. Zürich, p 87

Schönherr D (ed) (1867) Franz Schweygers Chronik der Stadt Hall 1303-1572. Tirolische Geschichtsquellen 1. Innsbruck

Seeböck P Ph (ed) (1882) Dreifache Chronik der Stadt Hall im Innthale. Ein historisches Manuskript als Ergänzung der Schweygerschen Chronik. Zeitschrift des Ferdinandeums für Tirol und Vorarlberg 3. F. 26. $\mathrm{H}$

StAH = Stadtarchiv Hall in Tirol, Miscellaneen, 28. (1689)

StAH = Stadtarchiv Hall in Tirol, Ratsprotokolle (1670)

StAI = Stadtarchiv Innsbruck, Ratsprotokoll (1572)

StAI = Stadtarchiv Innsbruck, Ratsprotokoll (1670)

StAI = Stadtarchiv Innsbruck, Ratsprotokoll (1689)

StAI = Stadtarchiv Innsbruck, Sammelakt 1/3

StAI = Stadtarchiv Innsbruck, Sammelakt 1/4

Straganz M (1896) Autobiographie des Freiherrn Jakob von Boimont zu Pairsberg. Sonderdruck aus dem Programm des k. k. Obergymnasiums der Franziskaner in Hall 1895-1896. Innsbruck

Theatrum Europaeum (1677) vol 10 / 2. Frankfurt am Main

Theatrum Europaeum (1698) vol 13. Frankfurt am Main

Tiedemann H (1992) Earthquake and Vulcanic Eruption, Zürich

Tinkhauser G, Rapp L (1879) Topographisch-historisch-statistische Beschreibung der Diözese Brixen: mit besonderer Berücksichtigung der Culturgeschichte und der noch vorhandenen Kunst- und Baudenkmale aus der Vorzeit. Bd. 2. Brixen, p 400

TLA = Tiroler Landesarchiv, Gemeine Missiven 1572 fol 1194 und 1607, In: Felmayr J (ed) (1981) Die Kunstdenkmäler der Stadt Innsbruck. Tl. 2. Die profanen Kunstdenkmäler der Stadt Innsbruck außerhalb der Altstadt. Österreichische Kunsttopographie. vol 45. Wien, Vienna

TLA, Abteilung Mariahilf. Rechnung wegen der durch den grossen erdbidem Anno 1689 beschechen reparation der lobl. tyrol. landschafft Maria hülf capellen. praes. 11. Aug. 1692; quittierte Rechnung Waldmanns von 1692. S. a.: Rampold R (1986) Die Pfarre und Pfarrkirche von Mariahilf in Innsbruck. Regensburg, p 12

TLA, Regierungskopialbücher (Nr. 53) (1572) fol.3r-3v

TLA, Salinenarchiv, Berichtsbücher, Salinenamtsbuch Nr 3/69 1670, 213 r, v 
TLA, Salinenarchiv, Salinenamtsbücher, Befehlsbücher 1/113 1670 fol 183

TLMF = Tiroler Landesmuseum FerdinandeumDipauliana 1080/2. Neue aigentliche und warhaffte beschreibung, denen von 17. Julii a. 1670 in vierzigtäg albereit anhaltenden Erdbeben. Ms. fol 2v-3r, 3v

TLMF, FB 4172: Würtenbergische Wochen-Protokolle vom Haller Salzberg (1660-1689) (1689)

TLMF, FB 4177, Vermischte Nachrichten vom k. k. Salzberg zu Hall im Ynnthall. 1777. Nr. XXXIII. a. b. Nr. 1. fol 120

TLMF, Würtenbergische Wochen-Protokolle vom Haller Salzberg (1660-1689) XXXIII. MS 4172, fol 21

Von Gümbel C W (1889) Das Erdbeben vom 22. Febr. 1889 in der Umgegend von Neuburg a. D. In: Sitzb. d. Münchner Akad. M. ph. Cl. 19. B. München, 79 ff

Von Hoff K E A (1840) Chronik der Erdbeben und Vulcan-Ausbrüche. Gotha, p 260

Weigl H (2007) Der, Neue Palast“ in Innsbruck. Ein erdbebensicherer Residenzbau von Christoph Gumpp. In: Engel M, Pozsgai M, Salge Ch, Weigl H (ed) Barock in Mitteleuropa. Wiener Jahrbuch für Kunstgeschichte vol 55/56, 2006/2007. Wien, pp 111-129 